\title{
Effect of biochar derived from faecal matter on yield and nutrient content of lettuce (Lactuca sativa) in two contrasting soils
}

\author{
Desta Woldetsadik ${ }^{1 *}$, Pay Drechsel ${ }^{2}$, Bernd Marschner ${ }^{3}$, Fisseha Itanna ${ }^{4}$ and Heluf Gebrekidan ${ }^{1}$
}

\begin{abstract}
Background: Faecal matter biochar offers an interesting value proposition where the pyrolysis process guaranties a $100 \%$ pathogen elimination, as well as significant reduction in transport and storage weight and volume. Therefore, to evaluate the effect of (1) biochar produced from dried faecal matter from household based septic tanks, and (2) $\mathrm{N}$ fertilizer, as well as their interaction on yield and nutrient status of lettuce (Lactuca sativa), lettuce was grown over two growing cycles under glasshouse on two contrasting soils amended once at the start with factorial combination of faecal matter biochar at four rates $\left(0,10,20\right.$ and $\left.30 \mathrm{tha}^{-1}\right)$ with 0,25 and $50 \mathrm{~kg} \mathrm{~N} \mathrm{ha}^{-1}$ in randomized complete block design.

Results: For both soils, maximum fresh yields were recorded with biochar and combined application of biochar with $\mathrm{N}$ treatments. However, the greatest biochar addition effects (with or without $\mathrm{N}$ ) with regard to relative yield were seen in less fertile sandy loam soil. We have also observed that faecal matter biochar application resulted in noticeable positive residual effects on lettuce yield and tissue nutrient concentrations in the 2 nd growing cycle. For both soils, most nutrients analyzed ( $\mathrm{N}, \mathrm{P}, \mathrm{K}, \mathrm{Mg}, \mathrm{Cu}$ and $\mathrm{Zn}$ ) were within or marginally above optimum ranges for lettuce under biochar amendment.

Conclusions: The application of faecal matter biochar enhances yield and tissue nutrient concentrations of lettuce in two contrasting soils, suggesting that faecal matter biochar could be used as an effective fertilizer for lettuce production at least for two growing cycles. Moreover, the conversion of the faecal matter feedstock into charred product may offer additional waste management benefit as it offers an additional (microbiologically safe) product compared to the more common co-composting.
\end{abstract}

Keywords: Biochar, Faecal matter, Waste management, Lettuce, Yield, Residual effects

\section{Background}

Biochar, which is carbonized biomass, is increasingly discussed as soil ameliorant with high potential (Lehmann and Joseph 2009). The ability of biochar to affect the fertility, carbon storage and remediation of soil varies with its characteristics (type of feedstock) as well as the temperature for its creation (Antal and Grønli 2003; Singh et al. 2010). As a result, some biochars may be better suited for one or more specific purposes for example

\footnotetext{
*Correspondence: destowol@yahoo.com

1 School of Natural Resources Management and Environmental Sciences, Haramaya University, 138, Dire Dawa, Ethiopia

Full list of author information is available at the end of the article
}

of agronomic performance, contaminant stabilization, or carbon sequestration (Enders et al. 2012; Abbasi and Anwar 2015; Agegnehu et al. 2015; Inal et al. 2015; Subedi et al. 2016). The application of biochar to agricultural land provides several potential benefits including enhancing the cation exchange capacity (CEC) (Glaser et al. 2001), water holding capacity (Gaskin et al. 2007), and improving organic carbon and nutrient contents of soils (Glaser et al. 2002). In addition, biochar may also be used in remediation of contaminated soil and water (Cao et al. 2009; Cao and Harris 2010). Most investigations on the use of biochar for soil fertility management was inspired by the occurrence of the anthropogenic Terra 
preta soil in Latin America (Glaser et al. 2001; Lehmann et al. 2003; Sombroek et al. 2003).

Using faecal matter as feedstock was a deliberate decision given the increasing competition for crop residues (mulching, livestock fodder, biogas, and composting), as well as their only seasonal availability. Using animal manure for biochar production as presented e.g. by Uzoma et al. (2011) and Hass et al. (2012) was not considered beneficial in Ethiopian context as animal manure is too valuable for this transformation. The use of animal as well as human manure has a long tradition in agriculture system, partly in raw form, partly after composting to minimize microbial risks (Powell et al. 1999; Guzha et al. 2005). The situation changed with increasing health regulations and household connections to sewer systems which increased the likelihood of chemical contamination where also industrial effluent feeds into the same sewage. However, rural and peri-urban households not connected to sewers but local septic tanks offer a significantly safer product (septage) for reuse than sewage sludge (Muchuweti et al. 2006; Singh and Agrawal 2007; Jamali et al. 2009). To address the possible stigma of fertilizer derived from human excreta, biochar offers an interesting value proposition where the pyrolysis process guaranties a $100 \%$ pathogen elimination, as well as significant reduction in transport and storage weight and volume (Tagoe et al. 2008). Moreover, compared with the long treatment process of composting the pyrolysis technology requires only few hours (Fytili and Zabaniotou 2008). On the other hand, the pyrolysis leads to significant losses of nitrogen (Calderón et al. 2006; Gaskin et al. 2008). Therefore, we were interested to study the co-application of faecal matter biochar and $\mathrm{N}$ fertilizer on the growth, yield and nutrient status of a popular cash crop, lettuce, used in urban farming across sub-Saharan Africa.

\section{Methods}

Soils

As the effect of biochar can vary significantly with soil characteristics, two different textural classes were targeted, a silty loam (soil 1) and sandy loam (soil 2). The soil material was collected for greenhouse experiments at the depth of $0-15 \mathrm{~cm}$ from two sites: an urban vegetable and a peri-urban groundnut farms in Addis Ababa and Babile, Ethiopia, respectively. Soil 1 had a long history of irrigated urban vegetable production using polluted river water. Soil 2 had a long history of rainfed groundnut production. The soils were each air-dried, sieved to $2 \mathrm{~mm}$, and homogenized.

\section{Biochar}

Faecal matter was collected at 12 locations from the top $10 \mathrm{~cm}$ of the septage drying area of the sewage disposal facility in Addis Ababa, Ethiopia, and mixed into one sample. For pyrolysis, the sample was placed in aluminum electric furnace (Fataluminum S.p.A, Italy). The air-inlet was covered to ensure a low oxygen condition. The heating rate was $15^{\circ} \mathrm{C} / \mathrm{min}$. Heat treatment was performed at $450{ }^{\circ} \mathrm{C}$. The pyrolysis temperature was maintained for an hour. After pyrolysis, the charred sample was removed from the canister and allowed to cool to room temperature.

\section{Pot trials}

Two independent pot experiments (soil 1, soil 2) were conducted in a temperature controlled glasshouse at National Soil Testing Centre, Addis Ababa, Ethiopia. The layout of each trial was 4 * 3 factorial involving 4 biochar $\left(0,10,20\right.$ and $\left.30 \mathrm{t} \mathrm{ha}^{-1}\right)$ and three $\mathrm{N}$ fertilizer rates $(0$, 25 and $50 \mathrm{~kg} \mathrm{~N} \mathrm{ha}^{-1}$ ) in one randomized complete block design. For each experiment, treatments were replicated five times. Three $\mathrm{kg}$ of each soil was mixed with biochar treatments. After 2 weeks of imposition on the corresponding pots, each pot was watered and allowed to settle for 5 days. After 5 days, 6 seeds of lettuce were sown per pot and thinned to 3 seedlings after emergence. Pots were placed on plastic saucers to prevent leachate drainage. Nitrogen fertilizer solution was prepared by mixing specified amount of urea with distilled water. At sowing 1/3 of the proposed $\mathrm{N}$ rates were added to the matching pots and $2 / 3$ of the proposed rates 6 weeks after emergence.

Two weeks after harvest, a second lettuce crop was grown in the same pots starting again with 6 seeds, continuing with 3 as described above. In the 2nd growing season, no treatment was applied but the required agronomic practices, such as weeding and watering, were maintained.

\section{Agronomic parameters}

At maturity, 9 weeks after sowing, lettuce plants were cut down to soil surface to determine above ground biomass (fresh weight). Therefore, leaves were cleaned from dust and soil particles using distilled water. Dry weight was subsequently determined following oven drying to a constant weight at $65^{\circ} \mathrm{C}$ for $72 \mathrm{~h}$.

\section{Analyses}

The soils and biochar samples were ground to $<2 \mathrm{~mm}$ for all chemical analysis but for Brunauer-Emmet-Teller (BET) specific surface area. For total element, C, N, $\mathrm{NH}_{4} \mathrm{NO}_{3}$ extractable trace elements and Fourier Transform Infrared (FTIR) analyses, samples were milled with a planetary ball mill to achieve a homogeneous fine powder (Fritsch GmbH, Idar-Oberstein, Germany). Similarly, the completely dried lettuce (oven drying at $65{ }^{\circ} \mathrm{C}$ for at least $72 \mathrm{~h}$ ) was ground, ball-milled to achieve a 
homogeneous fine powder. The $\mathrm{pH}$ of biochar in water was determined in 1:20 (w/v) ratio after occasionally stirring over an hour (Cheng et al. 2006). The $\mathrm{pH}$ of the soils in water suspensions were determined in 1:2.5 (w/v) ratio after shaking over $2 \mathrm{~h}$. The EC of the biochar was determined after an hour equilibration of $1 \mathrm{~g}$ of biochar with $20 \mathrm{ml}$ of distilled water. The EC of the soil samples were determined after $2 \mathrm{~h}$ equilibration of $1 \mathrm{~g}$ of soil with $2.5 \mathrm{ml}$ of distilled water. For total element analysis, $0.25 \mathrm{~g}$ samples of biochar and plant were placed into $50 \mathrm{ml}$ vessels, followed by addition of $10 \mathrm{ml}$ concentrated $\mathrm{HNO}_{3}$. The mixtures were left over night and then heated in 1.6 kilowatts microwave oven for $30 \mathrm{~min}$. After cooling to room temperature, $10 \mathrm{ml}$ of double distilled water were added into the vessels and filtered via $0.45 \mu \mathrm{m}$ cellulose nitrate filter papers. Finally, the filtrates were subjected to the total element analysis using ICP-OES (Ciros CCD, SPECTRO Analytical Instruments $\mathrm{GmbH}$, Kleve, Germany). Olsen-P (available P) was extracted by placing $1 \mathrm{~g}$ sample of soil in $20 \mathrm{ml}$ of $\mathrm{NaHCO}_{3}$ for $30 \mathrm{~min}$. Similar amount of biochar samples were placed in $20 \mathrm{ml}$ of $\mathrm{NaHCO}_{3}$ for $30 \mathrm{~min}$. The suspensions were vacuum filtered via $0.45 \mu \mathrm{m}$ cellulose nitrate filter papers and analyzed using ICP-OES (Ciros CCD, SPECTRO Analytical Instruments $\mathrm{GmbH}$, Kleve, Germany). For $\mathrm{C}$ and $\mathrm{N}$ analyses, $3.5 \mathrm{mg}$ for biochar, $5 \mathrm{mg}$ for plant and $40 \mathrm{mg}$ for soil, samples were weighted into sample boats and determined using $\mathrm{C}$ and $\mathrm{N}$ analyzer (Elementar Analyse $\mathrm{GmbH}$, Hanau, Germany). The exchangeable cations and CEC of biochar were determined using $\mathrm{BaCl}_{2}$ method. The exchangeable cations and $\mathrm{CEC}$ of soils were determined using $\mathrm{NH}_{4} \mathrm{Cl}$ method. $\mathrm{NH}_{4} \mathrm{NO}_{3}(1 \mathrm{M})$ extractable fractions of trace nutrients and toxic elements were also determined following the extraction procedure proposed by the German national standard (DIN ISO 10730 2009).

Soil particle size distributions were determined by laser diffraction using an Analysette 22 MicroTec plus (Fritsch $\mathrm{GmbH}$, Idar-Oberstein, Germany) with a wet dispersion unit. For FTIR analyses of biochar, pellets were prepared by mixing biochar with potassium bromide $(\mathrm{KBr})$ powder and then analyzed using a Tensor 27 FTIR Spectrometer (Bruker optik GmbH, Ettlingen, Germany). Spectra were collected in the range of $400-4000 \mathrm{~cm}^{-1}$ at $4 \mathrm{~cm}^{-1}$ and 120 scans per sample. Surface area of the biochar was determined using adsorption data of the adsorption isotherms of $\mathrm{N}_{2}$ at $-196{ }^{\circ} \mathrm{C}$ and calculated by the BrunauerEmmet-Teller (BET) equation (Brunauer et al. 1938). Total surface acidity (TSA) and basicity (TSB) were determined by Boehm titration (Boehm 1994).

\section{Statistical analyses}

An ANOVA, PROC mixed of SAS was used to test the significance of treatment effects on above ground biomass (fresh and dry weights) and above ground biomass nutrient concentrations. Data for 1st and 2nd growing cycles were analyzed separately. Orthogonal contrast tests compared yield and nutrient content response of $\mathrm{N}$ alone treatments $\left(25,50 \mathrm{~kg} \mathrm{~N} \mathrm{ha}^{-1}\right)$ together as a class versus control $\left(0 \mathrm{t} \mathrm{ha}^{-1}\right.$ biochar $\left.+0 \mathrm{~kg} \mathrm{~N} \mathrm{ha}^{-1}\right)$, biochar alone treatments $\left(10,20,30 \mathrm{t} \mathrm{ha}^{-1}\right)$ together as a class versus control, $\mathrm{N}$ alone treatments together as a class versus biochar alone treatments together as a class, biochar with $\mathrm{N}$ treatments $\left(10 \mathrm{t} \mathrm{ha}^{-1}+25 \mathrm{~kg} \mathrm{~N} \mathrm{ha}^{-1}\right.$, $10 \mathrm{tha}^{-1}+50 \mathrm{~kg} \mathrm{~N} \mathrm{ha}^{-1}, 20 \mathrm{t} \mathrm{ha}^{-1}+25 \mathrm{~kg} \mathrm{~N} \mathrm{ha}^{-1}$, $20 \mathrm{t} \mathrm{ha}^{-1}+50 \mathrm{~kg} \mathrm{~N} \mathrm{ha}^{-1}, 30 \mathrm{t} \mathrm{ha}^{-1}+25 \mathrm{~kg} \mathrm{~N} \mathrm{ha}^{-1}$, $30 \mathrm{t} \mathrm{ha}^{-1}+50 \mathrm{~kg} \mathrm{~N} \mathrm{ha}^{-1}$ ) together as a class versus biochar alone treatments together as a class and biochar with $\mathrm{N}$ treatments together as a class versus $\mathrm{N}$ alone treatments together as a class. Pearson's correlation coefficients were used to estimate relationships between fresh yield and tissue nutrient concentrations under increasing biochar levels with no N. Statistical tests with $p<0.05$ were considered significant for treatment/class effects.

\section{Results and discussion}

Characterization of the soils and faecal matter biochar

While soil 1 and 2 do not differ in their clay content (around 7-8\%) they differ significantly in the silt/sand ratio with 74/19 (soil 1) to 38/54 (soil 2). Despite same clay content soil 1 showed significantly higher levels of exchangeable cations is thus a result of the several times higher carbon content of soil 1 (1.9\%) compared to soil 2 $(0.3 \%)$. Available P (Olsen) follows the higher carbon levels of soil 1 (Table 1 ), and the $\mathrm{C} / \mathrm{N}$ ratio of both soils is in the same narrow range of 8-10. Compared with literature thresholds, soil 1 can be classified as moderately fertile while soil 2 misses several thresholds (Tadesse 1991; Peverill et al. 1999). The higher silt and carbon content of soil 1 can probably be related to its location which is a river bank of the Akaki river within Addis Ababa.

In agreement with the alkaline $\mathrm{pH}\left(\mathrm{H}_{2} \mathrm{O}\right)$ of manure derived biochars (Cantrell et al. 2012; Zhang et al. 2013), the faecal matter biochar had a $\mathrm{pH}\left(\mathrm{H}_{2} \mathrm{O}\right)$ of 8.23 (Additional file 1: Table S1). Faecal matter biochar also had low EC value $(0.34 \mathrm{dS} / \mathrm{m})$, whereas, biochar produced from poultry litter exhibited high EC value (Cantrell et al. 2012). These were expected considering the high ash content in manure derived biochars (Cantrell et al. 2012; Zhang et al. 2013; Qiu et al. 2014). Unlike the typical feature of plant based biochars, very high concentration of total $\mathrm{C}$ and very low total $\mathrm{N}$ concentration (Enders et al. 2012; Qiu et al. 2014; Woldetsadik et al. 2016), faecal matter biochar had very low concentration of total $\mathrm{C}$ (Additional file 1: Table S1). The total P, Fe, $\mathrm{Al}, \mathrm{Ca}$ and $\mathrm{Mg}$ concentrations of the biochar were high (Additional file 1: Tables S1, S2) and so the total contents of trace and 
toxic elements. However, with the exception of $\mathrm{Zn}$, total concentration of the trace and toxic elements were below or marginally exceed the International Biochar Initiative (IBI) accepted upper thresholds (IBI 2014) (Additional file 1: Table S2). According to IBI (2014), the accepted concentration range for $\mathrm{Cd}, \mathrm{Co}, \mathrm{Cr}, \mathrm{Cu}, \mathrm{Ni}$ and $\mathrm{Pb}$ were 1.4-39, 34-100, 93-1200, 143-6000, 47-420 and 121$300 \mathrm{mg} / \mathrm{kg}$, respectively. The biochar had high Olsen-P value of $1298 \mathrm{mg} / \mathrm{kg}$ (Additional file 1: Table S3). Concurrently, Fourier Transform Infrared (FTIR) analysis showed that the biochar had intense peak at $1038 \mathrm{~cm}^{-1}$, attributed to abundant $\mathrm{PO}_{4}{ }^{3-}$ concentration (Additional file 1: Figure S1) (Jiang et al. 2004). Yet again, faecal matter biochar had low ammonium nitrate extractable $\mathrm{Zn}$ compared to the total load (Additional file 1: Tables S2, S3). Ammonium nitrate extractable fraction was used to estimate the bioavailability of heavy metals in the examined biochars.

\section{Effect of biochar application on yield}

In both experiments, above ground biomass, fresh and dry weights, of lettuce was noticeably enhanced over the control and $\mathrm{N}$-alone $(\mathrm{P}<0.05)$ with the application of both treatments: biochar alone and biochar with $\mathrm{N}$ (Figs. 1, 2). The effect was most pronounced on the less fertile soil 2 and lasted over two growing cycles (Table 2). Similarly, greenhouse studies using different biochars showed that biochar application, with and without N, resulted in greater yield than the controls (Chan et al. 2007; Hossain et al. 2010). However, our results contrast with the findings of some investigators (Blackwell et al. 2010; Van Zwieten et al. 2010; Alburquerque et al. 2013) who found no or little response of crop yield to the sole use of biochar over the control and fertilized treatments. The stated difference can be partly attributed to the nutrient content of the original feedstock and pre-existing soil nutrient status. Nutrient-rich biochars like those produced from manure may directly supply nutrients to crops (Rajkovich et al. 2012). On the contrary, most studies on the crop production performance of plant-based biochars have shown that the beneficial effect of such biochars are most evident when biochar is combined with mineral fertilizers (Asai et al. 2009; Van Zwieten et al. 2010; Alburquerque et al. 2013).

The highest biochar and $\mathrm{N}\left(30 \mathrm{tha}^{-1}\right.$ with $\left.50 \mathrm{~kg} \mathrm{~N} \mathrm{ha}^{-1}\right)$ combined application resulted in the greatest (statistically) fresh yield response of lettuce plants in the 1st growing cycle, but equaled the impact of the lower $\mathrm{N}$ enrichment in the second cycle. Again, in both experiments, the highest biochar rate $\left(30 \mathrm{tha}^{-1}\right)$ significantly increased fresh yields more than the $10 \mathrm{t} \mathrm{ha}^{-1}$ biochar rate and as much or more than the $20 \mathrm{tha}^{-1}$ biochar rate, with 0,25 or $50 \mathrm{~kg} \mathrm{~N} \mathrm{ha}^{-1}$ rates, over both growing cycles.
$\mathrm{N}$ treatments without biochar led to slight increases with no significant effect, compared to the control. For both soils, the non-significant impact of low $\mathrm{N}$ levels on yield of lettuce could be partly attributed to the high demand of leafy vegetable including lettuce for N. Furthermore, the problem is severe in carbon depleted soil 2 having low clay and available P contents. For soil 2, the use of mineral fertilizers could not be viewed as a solution due to the limited ability of the low clay soil to retain nutrients due to low organic matter content (Lal 2006; Kimetu et al. 2008). In agreement with the findings of this study, Huett (1989) reported low yield response of various vegetable to low $\mathrm{N}$ addition. Decline in yield response of lettuce to low N was also reported by Thompson and Doerge (1996) and Sanchez (2000). Soil 1 which is a higher river bank soil with periodic flooding and had relatively high $\mathrm{C}$ and $\mathrm{N}$ contents, the crop $\mathrm{N}$ demand is probably covered by the soil. The possibility that high water nutrient loads improved soil fertility as e.g., reported by Kiziloglu et al. (2008) appeared less likely as the Akaki water is, despite its pollution, not comparable with untreated or preliminary treated wastewater.

In the soil 1 experiment, fresh yield increased linearly with increasing biochar application in the 1st growing cycle (Fig. 1). In both growing cycles, increasing levels of biochar positively correlated with fresh yields ( $r=0.72, P=0.0018$ for the 1 st growing cycle and $r=0.71, P=0.0022$ for the 2nd growing cycle). Also $\mathrm{N}$ fertilization increased yields, but only with increasing biochar application rates. Lettuce plants grown in pots amended with biochar alone class produced significantly $(\mathrm{P}<0.001)$ higher fresh yield than lettuce plants from $\mathrm{N}$ alone class over both growing cycles. Likewise, lettuce plants from biochar with $\mathrm{N}$ class was significantly $(\mathrm{P}<0.001)$ heavier in fresh and dry weights than plants from $\mathrm{N}$ alone and control classes (Table 2). In addition, fresh and dry matter yields were not significantly affected by $\mathrm{N}$ alone class compared to the control. In the 1st growing cycle, it was observed that the increase in fresh yield of lettuce plants under biochar with $\mathrm{N}$ class was statistically $(\mathrm{P}<0.001)$ greater than biochar alone class (significant difference between biochar with $\mathrm{N}$ versus biochar alone class). Conversely, the fresh and dry matter yield responses were not significant in the 2nd growing cycle (Table 2). The residual effect of $\mathrm{N}$ was also nonsignificant in yield responses, implying that the initial $\mathrm{N}$ application was either taken up, not relevant and/or lost. In the same experiment, fresh yield was positively correlated with tissue $\mathrm{P}, \mathrm{K}$, and $\mathrm{P} / \mathrm{Zn}$ and negatively correlated with $\mathrm{N} / \mathrm{P}, \mathrm{Cu}$ and $\mathrm{Zn}$ under increasing rates of biochar giving correlation coefficients of $0.78^{* * * *}, 0.68^{* * *}, 0.83^{* * * *}$, $-0.79^{* * * *},-0.81^{* * * *}$ and $-0.36 \mathrm{~ns}$, respectively, in the 1st growing cycle. In the 2nd growing cycle, fresh yield was 


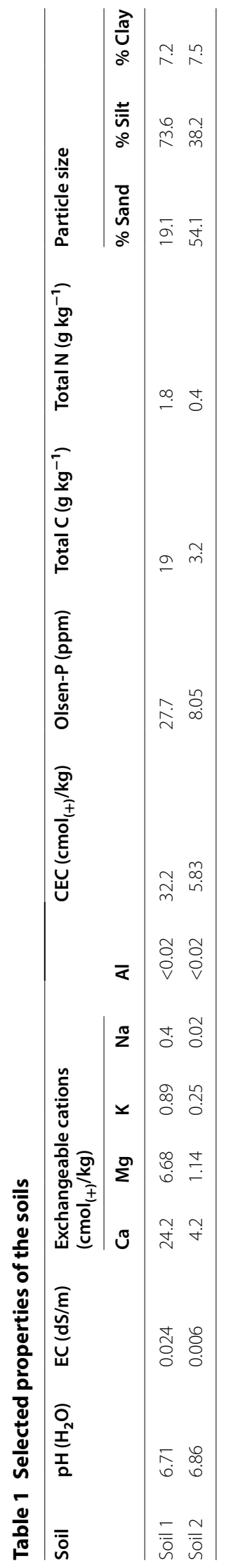




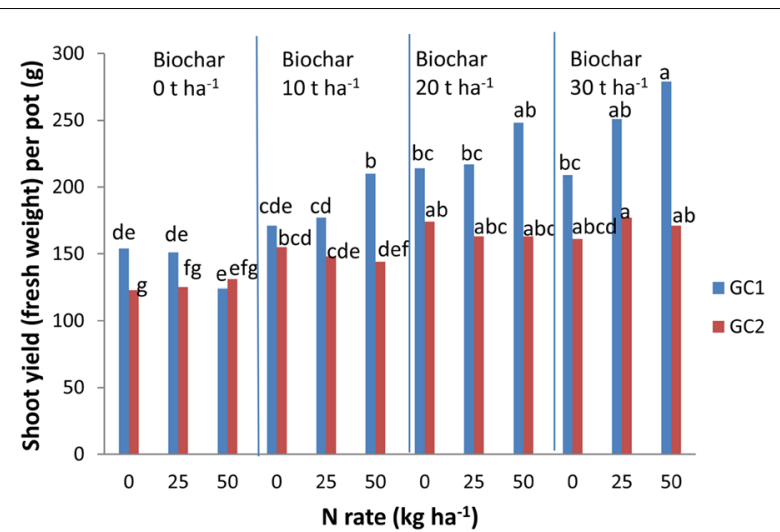

Fig. 1 Shoot yield (fresh weight) of lettuce grown on soil 1 under different biochar and N application rates. Growing cycle $1=\mathrm{GC} 1$ and Growing cycle $2=\mathrm{GC2}$. Values for each growing cycle with different letter within each bar are significantly different $(P<0.05)$

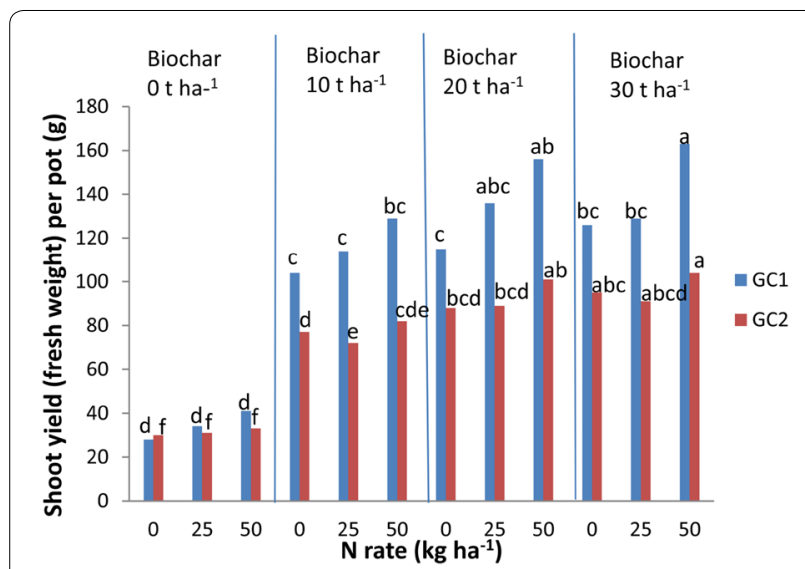

Fig. 2 Shoot yield (fresh weight) of lettuce grown on soil 2 under different biochar and N application rates. Growing cycle 1 = GC1 and Growing cycle $2=\mathrm{GC2}$. Values for each growing cycle with different letter within each bar are significantly different $(P<0.05)$

positively correlated with tissue $\mathrm{P}, \mathrm{K}$, and $\mathrm{Zn}$ and negatively correlated with $\mathrm{N} / \mathrm{P}$ and $\mathrm{Cu}$. The dilution effect and/or $\mathrm{pH}$ and $\mathrm{P}$-induced $\mathrm{Cu}$ immobilization may be attributed to the strong negative relationship between yield and $\mathrm{Cu}$ content of lettuce plants. Responses of lettuce to concurrent use of biochar with less $\mathrm{N}$ were beneficial in terms of fresh yield in this soil. The correlation results suggested that addition of extra $\mathrm{N}$ may maintain detrimental yield effect.

In the 1st growing cycle of the soil 2 experiment, biochar alone class increased fresh yield by $211 \%$ relative to $\mathrm{N}$ alone class (Table 2). However, the increase was only by $45 \%$ in soil 1. Despite the fact that increasing biochar levels significantly correlated with fresh yield in both soils over both growing cycles, stronger correlation was observed in soil 2 than in soil $1(r=0.87, P<0.0001$ for the 1st growing cycle and $r=0.91, P<0.0001$ for the 2nd growing cycle). These results reflect the fact that the effect of biochar depend on the fertility status of the soil (Alburquerque et al. 2013). Contrast tests also showed that the residual effect of biochar alone class increased yield by $172 \%$ compared to $\mathrm{N}$ alone class in soil 2. Much stronger than in soil 1, the increase in fresh and dry matter yields under biochar with $\mathrm{N}$ class/treatments were statistically $(\mathrm{P}<0.001)$ greater than biochar alone class/treatments in the 1st growing cycle (Table 2; Fig. 2). The $\mathrm{N}$ alone and control treatments produced statistically similar lettuce fresh weight over both growing cycles (Fig. 2). In first growing cycle, fresh yield positively correlated with tissue $\mathrm{N}, \mathrm{P}, \mathrm{K}, \mathrm{Mg}$, and $\mathrm{P} /$ $\mathrm{Zn}$ in response to an increase in biochar levels giving correlation coefficients of $0.47 \mathrm{~ns}, 0.87^{* * * *}, 0.69^{* * *}, 0.82^{* * * *}$, and 0.90 , respectively, while negative correlation was observed with $\mathrm{Cu}(r=-0.93, P<0.0001), \mathrm{Zn}(r=-0.25, P=0.3461)$ and N/P $(r=-0.87, P<0.0001)$. Previous pot experiment has shown that biochar addition at higher rates positively correlated with yield of Radish (Chan et al. 2007). This previous study also demonstrated the increased yield of Radish with increasing levels of biochar is attributed to the increased supply of $\mathrm{P}$ and $\mathrm{K}$, but, unlike the current study, depicted non-significant correlation of yield with tissue $\mathrm{Mg}$ concentration. The results indicated that increasing biochar levels significantly increased fresh yield and selected tissue macro and micro nutrient contents and their ratios (P, K, $\mathrm{Mg}$, and $\mathrm{P} / \mathrm{Zn}$ ) but significant negative effect was observed for tissue $\mathrm{Cu}$ and N/P. Hence, the very low yield in the control and $\mathrm{N}$ treatments may have resulted from the reduced availability and uptake of $\mathrm{P}, \mathrm{K}$ and $\mathrm{Mg}$.

For soil 2, the tissue $\mathrm{P}$ concentration and $1000 \mathrm{P} / \mathrm{Zn}$ ratios for $\mathrm{N}$ alone and control treatments were below the optimum range of $3.5-8.0 \mathrm{~g} / \mathrm{kg}$ (dry weight), and 700930, respectively, (Ludwick 2002; Hartz and Johnstone 2007), whereas, the N/P ratio was far above the optimum range, suggesting $\mathrm{P}$ availability was limiting. The tissue $\mathrm{P}, \mathrm{P} / \mathrm{Zn}$ (few exceed the optimum range) and N/P ratios for biochar treatments (biochar alone and biochar with $\mathrm{N})$ were within the optimum range. On the other hand, data obtained from soil 1 study demonstrated that the tissue $\mathrm{P}$ concentrations for all treatments but control were within the optimum range, despite the significant difference in yield of lettuce plants grown under the biochar treatments compared to $\mathrm{N}$ alone treatments. The yield increment could be partly attributed to the added plant nutrients, particularly $\mathrm{P}, \mathrm{K}$ and $\mathrm{Mg}$ and corresponding uptake by lettuce plants under biochar application. This result is consistent with the findings of Johnstone et al. (2005) who reported pronounced yield response of lettuce to $\mathrm{P}$ fertilizer in soil with high available P status. This 
Table 2 Class means and contrasts of class for fresh yield and dry matter yield of lettuce grown in Soil $\mathbf{1}$ and 2 for two growing cycles

\begin{tabular}{|c|c|c|c|c|c|c|c|c|}
\hline \multirow[t]{3}{*}{ Class comparison } & \multicolumn{4}{|l|}{ Soil 1} & \multicolumn{4}{|c|}{ Soil 2} \\
\hline & \multicolumn{2}{|c|}{ Fresh yield } & \multicolumn{2}{|c|}{ Dry matter yield } & \multicolumn{2}{|c|}{ Fresh yield } & \multicolumn{2}{|c|}{ Dry matter yield } \\
\hline & $\mathrm{GC}^{\mathrm{a}}$ & GC2 & GC1 & GC2 & GC1 & GC2 & GC1 & GC2 \\
\hline Classes & $\mathrm{g} / \mathrm{pot}$ & & & & & & & \\
\hline Control & 154 & 123 & 9.5 & 7.4 & 28 & 30 & 1.8 & 2.0 \\
\hline $\mathrm{N}$ alone & 137 & 128 & 8.2 & 7.7 & 37 & 32 & 2.4 & 2.3 \\
\hline Biochar alone & 198 & 163 & 11.7 & 9.7 & 115 & 87 & 7.0 & 5.5 \\
\hline Biochar with N & 230 & 161 & 13.4 & 9.4 & 138 & 90 & 8.2 & 5.5 \\
\hline \multicolumn{9}{|l|}{ Contrasts $^{\mathrm{b}}$} \\
\hline Control versus biochar alone & $* * *$ & $* * *$ & $* * *$ & $* * *$ & $* * *$ & $* * *$ & $* * *$ & $* * *$ \\
\hline Control versus $\mathrm{N}$ alone & ns & ns & ns & ns & ns & ns & ns & ns \\
\hline Biochar alone versus $\mathrm{N}$ alone & $* * *$ & $* * *$ & $* * *$ & $* * *$ & $* * *$ & $* * *$ & $* * *$ & $* * *$ \\
\hline Biochar with $\mathrm{N}$ versus biochar alone & $* * *$ & ns & $* * *$ & ns & $* * *$ & ns & *** & ns \\
\hline Biochar with $\mathrm{N}$ versus $\mathrm{N}$ alone & $* * *$ & $* * *$ & $* * *$ & $* * *$ & $* * *$ & $* * *$ & $* * *$ & $* * *$ \\
\hline
\end{tabular}

a $\mathrm{GC1}=$ Growing Cycle I and GC 2 = Growing Cycle II

${ }^{b}$ Classes compared comprise the following treatments: control $=$ control; biochar alone $=$ biochar alone treatments $\left(10,20\right.$ and $30 \mathrm{t} \mathrm{ha}{ }^{-1}$ )

$\mathrm{N}$ alone $=\mathrm{N}$ alone treatments $\left(25,50 \mathrm{~kg} \mathrm{~N} \mathrm{ha}^{-1}\right)$; biochar with $\mathrm{N}=$ combination of the different biochar rates with the two $\mathrm{N}$ levels

$n s$, not significant $(P>0.05)$; ${ }^{*} P<0.05$; ${ }^{* *} \mathrm{P}<0.01$; $\left.{ }^{* *} \mathrm{P}<0.001\right), \mathrm{n}=5$

is further confirmed by Cleaver and Greenwood (1975) who reported high $\mathrm{P}$ fertilizer requirements of lettuce than most other vegetables across a range of soils. Therefore, on one hand, the increased lettuce yield in biochar amended soils may have resulted from the fertilization effect of the biochar in both soils (Sohi et al. 2010; Liu et al. 2012). Nevertheless, several studies have demonstrated the positive impact of biochar on crop yield via restoring soil organic carbon (SOC) (Lal 2004, 2010; Spokas et al. 2012; Biederman and Harpole 2013). Increasing the SOC pool of degraded soils would increase crop yields by influencing water retention capacity, nutrient exchange capacity and soil structure and other physical properties (Lal 2006; Steiner et al. 2007; Novak et al. 2009; Pan et al. 2009). For example, in Kenya, Kimetu et al. (2008) have demonstrated a low level of $3 \mathrm{t}$ maize grain $\mathrm{ha}^{-1}$ at degraded sites despite full N-P-K fertilization (120-100$100 \mathrm{~kg} \mathrm{ha}^{-1}$ ). Conversely, application of organic resources including biochar reversed the productivity decline by increasing yields by $57-167 \%$. The positive impact of biochar on maize grain yield at degraded sites were not fully explained by nutrient availability, suggesting restoration of SOC as improvement factor other than plant nutrition. For low SOC calcareous soil, application of $40 \mathrm{tha}^{-1}$ biochar promoted significant maize grain yield increase compared to the control with an increase in the 57.8\% SOC pool (Zhang et al. 2012b). Productivity gains are large, especially when the organic feedstock source has high quality in terms of nutrient load (Lal 2006; Kimetu et al. 2008). Increases in SOC concentration enhance crop productivity in soils with a clay content lower than 20 per cent, and in soils of sandy-loam and loamy-sand texture (Lal 2006). Hence, on the other hand, the increased lettuce yield in biochar amended soils with low clay contents of around 7-8\% may also partly resulted from the improvement of soil organic matter, particularly in carbon and nitrogen depleted soil 2.

Despite the 14 weeks elapsed between lettuce plants removed and subsequent planting of a second lettuce crop, residual effect of biochar, with or without $\mathrm{N}$, significantly increased fresh yield of lettuce compared with the control and both $\mathrm{N}$ alone treatments. Our results were similar to those of Vaccari et al. (2011) who reported that the yield effect of biochar did continue into a subsequent cropping season. Other biochar studies also revealed that crop yields were the same as or greater than controls in the second cropping cycle after biochar application (Steiner et al. 2007; Gaskin et al. 2010; Zhang et al. 2012a). Unger and Killorn (2012), however, reported non-significant yield increase from biochar residual effect. The difference in feedstock origin, surface oxidation and CEC of biochar seem to cause varied direct and residual effects on growth and yield of crops (Liang et al. 2006). Consequently, such a significant residual yield increment could partly be associated with a likely marked increase of important plant macronutrients such as $\mathrm{P}, \mathrm{K}$ and $\mathrm{Mg}$ and to lesser extent possible $\mathrm{N}$ mineralization in the soils. Moreover, having low CEC value for soil 2, 
the biochar could possibly enhance ability of this soil to retain cations.

Biosolids are known to contain high total concentrations of trace and toxic elements, which exist in more pronounced concentrations in charred product (Bridle and Pritchard 2004; Lu et al. 2013). One detrimental effect of biosolid including waste derived biochar use is the accumulation of heavy metals concomitantly reduction of crop growth at higher application rates (Walter et al. 2006; Singh and Agrawal 2007). Ammonium nitrate extractable fraction was used to estimate the bioavailability of micro-nutrient/heavy metals in the biochar which was used as an amendment in this study. In our case, even the highest biochar rate $\left(30 \mathrm{tha}^{-1}\right)$ did not induce reduction of yields, as yields were always statistically $(\mathrm{P}<0.05)$ higher than or equal to the lower biochar rates, indicating lower phytotoxicity effect as a consequence of very low $\mathrm{NH}_{4} \mathrm{NO}_{3}$ extractable heavy metal fractions (Additional file 1: Table S3) and phyto-availability of the metals for the test crop. However it is crucial to investigate the long-term effects of the biochar on dynamics of heavy metal in amended soils (Woldetsadik et al. 2016).

\section{Effect of biochar application on tissue nutrient concentrations}

In both experiments, with the exception of $\mathrm{N}$ alone treatments, all other biochar alone and biochar with $\mathrm{N}$ treatments promoted significant $(\mathrm{P}<0.05)$ tissue $\mathrm{P}$ concentrations in the 1st growing cycle (Tables 3,4$)$. In soil 1 experiment, all treatments but the lowest biochar alone level $\left(10 \mathrm{tha}^{-1}\right)$ induced significant residual tissue $\mathrm{P}$ concentrations compared to the control. However, the residual tissue $\mathrm{P}$ contents were not significantly affected by $\mathrm{N}$ alone treatments in soil 2 . On the contrary to the stated observations, results of recent studies revealed that application of biochar hardly impact P levels of crops (Kloss et al. 2014; Reibe et al. 2015). Earlier study by Gaskin et al. (2010) also revealed that application of pine chip biochar did not significantly affect tissue P content of corn crop. Due to high available P load, the biochar used in these experiments positively influenced lettuce $\mathrm{P}$ content and yield. Likewise, P-rich soil amendments including manure-derived biochars seem to represent a significant source of P (Chan et al. 2008; Asai et al. 2009; Uzoma et al. 2011). This was confirmed by the strong correlations of increasing biochar levels with tissue $\mathrm{P}$ concentrations and fresh yields. Overall, the biochar had positive impact on tissue $\mathrm{P}$ concentration of lettuce plants grown on the two contrasting soils, though the magnitude of responses were quite different. We believed that the difference on tissue $\mathrm{P}$ concentration responses over the two soils might be attributed to the obtained difference in their available P contents. The relatively less fertile sandy loam soil (soil 2) with low available P status was expected to respond differently to biochar application than the silty loam (soil 1) having optimum Olsen-P value. In soil 1 , the greatest $(\mathrm{P}<0.05)$ tissue concentrations of $\mathrm{P}$ were obtained by the combined application of $20 \mathrm{tha}^{-1}$ biochar with $50 \mathrm{~kg} \mathrm{~N} \mathrm{ha}^{-1}$ and $30 \mathrm{tha}^{-1}$ with $25 \mathrm{~kg} \mathrm{~N} \mathrm{ha}^{-1}$ over both growing cycles. However, in soil 2 , the greatest (statistically) tissue $\mathrm{P}$ concentration was recorded using the highest level combination of biochar with $\mathrm{N}$ (30 t ha ${ }^{-1}$ with $50 \mathrm{~kg} \mathrm{~N} \mathrm{ha}^{-1}$ ) over the 1st growing cycle.

During the 1st growing cycle of soil 1, biochar application (with or without $\mathrm{N}$ ) significantly increased tissue $\mathrm{K}$ concentration compared to $\mathrm{N}$ alone and control treatments (Table 3). Addition of $\mathrm{N}$ in soil 2 did not provide significant increase in tissue $\mathrm{K}$ concentration over both growing cycles. However, $\mathrm{N}$ application promoted significant tissue $\mathrm{K}$ concentration in soil 1 . With the exception of the lowest biochar level $\left(10 \mathrm{t} \mathrm{ha}^{-1}\right)$, all biochar treatments, with and without $\mathrm{N}$, induced significant residual tissue $\mathrm{K}$ concentrations in both soils. For both soils, tissue $\mathrm{K}$ concentrations of all biochar treatments but two biochar with $\mathrm{N}$ combinations in the 1st growing cycle of soil $2\left(30 \mathrm{t} \mathrm{ha}^{-1}\right.$ with $50 \mathrm{~kg} \mathrm{~N} \mathrm{ha}^{-1}$ and $20 \mathrm{t} \mathrm{ha}^{-1}$ with $50 \mathrm{~kg} \mathrm{~N} \mathrm{ha}^{-1}$ ) were within the optimum range (Ludwick 2002). These results imply that the biochar served as a source of $\mathrm{K}$ beyond one cropping cycle likewise available P. Generally, the increase in tissue $\mathrm{K}$ content in response to biochar application in this study is in conformity with the findings of several researchers (Chan et al. 2007; Steiner et al. 2007; Chan et al. 2008; Gaskin et al. 2010), who were able to establish that the increase was due to high concentration of available $\mathrm{K}$ in biochars. Given the high $\mathrm{N}$ content with a very low $\mathrm{C}$ to $\mathrm{N}$ ratio $(\mathrm{C} / \mathrm{N}=9.7)$ of the biochar, the tissue $\mathrm{N}$ content of lettuce plants under biochar application was expected to be high. However, biochar application, without $\mathrm{N}$, did not increase tissue $\mathrm{N}$ content even at the highest rate of application $\left(30 \mathrm{tha}^{-1}\right)$ compared to $\mathrm{N}$ alone applications in the 1st growing cycle of both soils, indicating that $\mathrm{N}$ of biochar was not available for uptake over the short term (12 weeks). These results contrast with the findings of Chan et al. (2008) and Tagoe et al. (2008) who reported that biochars derived from $\mathrm{N}$ rich feedstock did furnish $\mathrm{N}$ for plants in the 1st cropping cycle. During the 2nd growing cycle, with the exception of the lowest $\mathrm{N}$ level $\left(25 \mathrm{~kg} \mathrm{~N} \mathrm{ha}^{-1}\right)$ for soil 1 and biochar level $\left(10 \mathrm{t} \mathrm{ha}^{-1}\right)$ for soil 2, all biochar treatments induced significant residual tissue $\mathrm{N}$ concentrations compared to the controls. In both experiments contrast tests also showed that biochar with $\mathrm{N}$ class produced lettuce plants of significantly lower tissue $\mathrm{N}$ concentration compared to $\mathrm{N}$ alone class in the 1st growing cycle (Additional file 2: Table 4S, 5S). Conversely, biochar with $\mathrm{N}$ class promoted 
Table 3 Treatment means for mineral concentrations (dry weight) of lettuce grown in soil 1 from the 1 st and the 2 nd growing cycles

\begin{tabular}{|c|c|c|c|c|c|c|c|c|c|c|c|c|}
\hline \multirow{3}{*}{$\begin{array}{l}\text { Biochar } \\
(\mathrm{t} / \mathrm{ha})\end{array}$} & \multicolumn{12}{|c|}{ Nitrogen Fertilizer rate $(\mathrm{kg} \mathrm{N} / \mathrm{ha})$} \\
\hline & \multicolumn{6}{|c|}{$1^{\text {st }}$ growing cycle } & \multicolumn{6}{|c|}{$2^{\text {nd }}$ growing cycle } \\
\hline & 0 & 25 & 50 & 0 & 25 & 50 & 0 & 25 & 50 & 0 & 25 & 50 \\
\hline & \multicolumn{3}{|c|}{$\mathbf{N}$} & \multicolumn{3}{|c|}{$\mathbf{P}$} & \multicolumn{3}{|c|}{$\mathbf{N}$} & \multicolumn{3}{|c|}{$\mathbf{P}$} \\
\hline 0 & $35.3 \mathrm{c}$ & $36.9 \mathrm{bc}$ & $42.7 \mathrm{a}$ & $3.44 \mathrm{~d}$ & $3.43 \mathrm{~d}$ & $3.74 \mathrm{~d}$ & $23.6 \mathrm{~g}$ & $25.8 \mathrm{efg}$ & $30.9 \mathrm{ab}$ & $3.29 \mathrm{~g}$ & $4.25 \mathrm{ef}$ & $4.73 \mathrm{de}$ \\
\hline 10 & $30.1 \mathrm{e}$ & $39.1 \mathrm{~b}$ & $33.8 \mathrm{~cd}$ & $4.13 \mathrm{~d}$ & $6.34 \mathrm{bc}$ & $6.57 \mathrm{bc}$ & 26.6def & $30.2 \mathrm{abc}$ & $32.1 \mathrm{a}$ & $3.62 \mathrm{fg}$ & $5.13 \mathrm{~d}$ & $5.30 \mathrm{~cd}$ \\
\hline 20 & $33.6 \mathrm{~cd}$ & $30.6 \mathrm{e}$ & $38.6 \mathrm{~b}$ & $6.91 \mathrm{~b}$ & $6.00 \mathrm{c}$ & $7.59 \mathrm{a}$ & $29.1 \mathrm{bc}$ & $28.0 \mathrm{cde}$ & $31.9 \mathrm{a}$ & $5.35 \mathrm{bcd}$ & $5.93 \mathrm{bc}$ & $7.34 \mathrm{a}$ \\
\hline \multirow[t]{2}{*}{30} & $30.7 \mathrm{e}$ & $27.8 \mathrm{f}$ & $31.8 \mathrm{de}$ & $6.89 \mathrm{~b}$ & $8.20 \mathrm{a}$ & $6.40 \mathrm{bc}$ & $26.7 \mathrm{def}$ & $24.3 \mathrm{fg}$ & $28.6 \mathrm{bcd}$ & $5.93 \mathrm{bc}$ & $7.52 \mathrm{a}$ & $6.10 \mathrm{~b}$ \\
\hline & \multicolumn{3}{|c|}{$\mathbf{K}$} & \multicolumn{3}{|c|}{$\mathrm{Ca}$} & \multicolumn{3}{|c|}{$\mathbf{K}$} & \multicolumn{3}{|c|}{$\mathbf{C a}$} \\
\hline 0 & $35.2 \mathrm{e}$ & $39.4 \mathrm{~d}$ & $39.6 \mathrm{~d}$ & $13.8 \mathrm{fg}$ & $13.4 \mathrm{f}$ & $12.0 \mathrm{fg}$ & $29.1 \mathrm{f}$ & $35.2 \mathrm{de}$ & $37.5 \mathrm{~cd}$ & $9.05 \mathrm{f}$ & $10.6 \mathrm{efg}$ & $9.98 \mathrm{efg}$ \\
\hline 10 & $39.4 \mathrm{~d}$ & $61.5 \mathrm{a}$ & $53.5 \mathrm{bc}$ & $10.3 \mathrm{~g}$ & $18.7 \mathrm{bc}$ & $18.9 \mathrm{bc}$ & $31.3 \mathrm{ef}$ & $38.8 \mathrm{~cd}$ & $47.8 \mathrm{~b}$ & $8.29 \mathrm{~g}$ & $13.4 \mathrm{~d}$ & $16.3 \mathrm{bc}$ \\
\hline 20 & $51.3 \mathrm{c}$ & $59.1 \mathrm{a}$ & $58.8 \mathrm{a}$ & $17.1 \mathrm{~cd}$ & $15.6 \mathrm{de}$ & $19.3 \mathrm{ab}$ & $41.1 \mathrm{c}$ & $41.8 \mathrm{c}$ & $52.8 \mathrm{ab}$ & $11.5 \mathrm{def}$ & $12.4 \mathrm{de}$ & $17.4 \mathrm{ab}$ \\
\hline \multirow[t]{2}{*}{30} & $60.9 \mathrm{a}$ & $55.4 \mathrm{~b}$ & $59.2 \mathrm{a}$ & $16.4 \mathrm{~d}$ & $16.4 \mathrm{~d}$ & $21.2 \mathrm{a}$ & $51.1 \mathrm{~b}$ & $50.0 \mathrm{~b}$ & $56.8 \mathrm{a}$ & $14.0 \mathrm{~cd}$ & $13.6 \mathrm{~cd}$ & $19.5 \mathrm{a}$ \\
\hline & \multicolumn{3}{|c|}{ Mg } & \multicolumn{3}{|c|}{$\mathrm{Cu}$} & \multicolumn{3}{|c|}{ Mg } & \multicolumn{3}{|c|}{$\mathrm{Cu}$} \\
\hline 0 & $4.84 \mathrm{f}$ & $5.14 \mathrm{ef}$ & $5.85 \mathrm{cde}$ & $12.5 \mathrm{a}$ & $11.9 \mathrm{ab}$ & $10.1 \mathrm{~cd}$ & $3.96 \mathrm{~d}$ & $4.45 \mathrm{~cd}$ & $4.59 \mathrm{~cd}$ & $10.6 \mathrm{a}$ & $9.86 a b c$ & 9.04abcd \\
\hline 10 & $5.27 \mathrm{def}$ & $5.13 \mathrm{ef}$ & $6.22 b c$ & $10.6 b c$ & $9.76 \mathrm{~cd}$ & $10.9 \mathrm{bc}$ & $4.42 \mathrm{~cd}$ & $4.52 \mathrm{~cd}$ & $5.15 \mathrm{abc}$ & $9.55 \mathrm{abc}$ & $7.68 \mathrm{~d}$ & 9.40abcd \\
\hline 20 & $6.85 \mathrm{ab}$ & $5.91 \mathrm{~cd}$ & $7.30 \mathrm{a}$ & $9.77 \mathrm{~cd}$ & $9.05 \mathrm{~d}$ & $9.68 \mathrm{~cd}$ & $5.21 \mathrm{abc}$ & $5.08 \mathrm{bc}$ & $5.75 \mathrm{ab}$ & 8.86abcd & 8.92abcd & 8.84abcd \\
\hline \multirow[t]{2}{*}{30} & $6.57 \mathrm{abc}$ & $5.16 \mathrm{ef}$ & $6.58 \mathrm{abc}$ & $9.03 \mathrm{~d}$ & $9.33 \mathrm{~cd}$ & $9.13 \mathrm{~d}$ & $5.51 \mathrm{abc}$ & $4.72 \mathrm{bcd}$ & $6.24 \mathrm{a}$ & $8.17 \mathrm{bcd}$ & $8.49 \mathrm{bcd}$ & $7.95 \mathrm{~cd}$ \\
\hline & \multicolumn{3}{|c|}{ Zn } & \multicolumn{6}{|c|}{$\mathbf{Z n}$} & & & \\
\hline 0 & $61.1 \mathrm{abc}$ & $59.3 \mathrm{abc}$ & $56.9 \mathrm{bc}$ & & & & $55.4 \mathrm{bcd}$ & $54.4 \mathrm{bcd}$ & $47.1 \mathrm{~d}$ & & & \\
\hline 10 & $57.3 \mathrm{bc}$ & $62.0 \mathrm{abc}$ & $63.4 \mathrm{ab}$ & & & & $57.0 \mathrm{bcd}$ & $58.7 \mathrm{abc}$ & $64.2 \mathrm{ab}$ & & & \\
\hline 20 & $58.3 \mathrm{bc}$ & $55.1 \mathrm{c}$ & $66.7 \mathrm{a}$ & & & & $55.2 \mathrm{bcd}$ & $54.1 \mathrm{~cd}$ & $67.9 \mathrm{a}$ & & & \\
\hline 30 & $59.6 \mathrm{abc}$ & $58.1 \mathrm{bc}$ & 61.4abc & & & & $59.0 \mathrm{abc}$ & $59.9 \mathrm{abc}$ & $63.2 \mathrm{abc}$ & & & \\
\hline
\end{tabular}

$\mathrm{Cu}$ and $\mathrm{Zn}$ in $\mathrm{mg} / \mathrm{kg}$; all other nutrients in $\mathrm{g} / \mathrm{kg}$

Mean of four replicates. Mean value followed by different letters in the shaded block for each variable significantly differ at the $5 \%$ level, according to the adjusted turkey test

Table 4 Treatment means for mineral concentrations (dry weight) of lettuce grown in soil 2 from the 1 st and the 2 nd growing cycles

\begin{tabular}{|c|c|c|c|c|c|c|c|c|c|c|c|c|}
\hline \multirow{4}{*}{$\begin{array}{l}\text { Biochar } \\
\text { (t/ha) }\end{array}$} & \multicolumn{12}{|c|}{ Nitrogen Fertilizer rate $(\mathrm{kg} \mathrm{N} / \mathrm{ha})$} \\
\hline & \multicolumn{6}{|c|}{$1^{\text {st }}$ growing cycle } & \multicolumn{6}{|c|}{$2^{\text {nd }}$ growing cycle } \\
\hline & 0 & 25 & 50 & 0 & 25 & 50 & 0 & 25 & 50 & 0 & 25 & 50 \\
\hline & \multicolumn{3}{|c|}{$\mathbf{N}$} & \multicolumn{3}{|c|}{$\mathbf{P}$} & \multicolumn{3}{|c|}{$\mathbf{N}$} & \multicolumn{3}{|c|}{$\mathbf{P}$} \\
\hline 0 & $24.4 \mathrm{ef}$ & $30.2 b$ & $29.8 \mathrm{bc}$ & $2.60 \mathrm{e}$ & $2.47 \mathrm{e}$ & $2.83 \mathrm{e}$ & $22.0 \mathrm{f}$ & $26.0 \mathrm{~cd}$ & $26.7 \mathrm{bc}$ & $2.55 \mathrm{e}$ & $2.77 \mathrm{e}$ & $2.97 \mathrm{e}$ \\
\hline 10 & $23.4 \mathrm{f}$ & $26.0 \mathrm{def}$ & $27.1 \mathrm{~d}$ & $6.44 b c$ & $5.93 \mathrm{~d}$ & $6.78 b$ & $21.4 \mathrm{f}$ & $23.3 \mathrm{e}$ & $23.4 \mathrm{e}$ & $5.27 \mathrm{~cd}$ & $4.88 \mathrm{~d}$ & $5.17 \mathrm{~cd}$ \\
\hline 20 & $27.5 \mathrm{c}$ & $27.0 \mathrm{~d}$ & $32.9 \mathrm{a}$ & $6.78 b$ & $6.31 \mathrm{~cd}$ & $6.13 \mathrm{~cd}$ & $25.3 \mathrm{~d}$ & $26.7 \mathrm{bc}$ & $28.6 \mathrm{a}$ & $6.05 b c$ & $6.10 \mathrm{bc}$ & $6.42 \mathrm{ab}$ \\
\hline \multirow[t]{2}{*}{30} & $27.1 d$ & $30.9 \mathrm{ab}$ & $30.7 \mathrm{ab}$ & $6.33 b c$ & $6.50 \mathrm{bc}$ & $7.34 \mathrm{a}$ & $23.9 \mathrm{e}$ & $25.3 \mathrm{~d}$ & $27.3 \mathrm{ab}$ & $6.16 \mathrm{bc}$ & $6.66 \mathrm{ab}$ & $7.30 \mathrm{a}$ \\
\hline & \multicolumn{3}{|c|}{ K } & \multicolumn{3}{|c|}{$\mathrm{Ca}$} & \multicolumn{3}{|c|}{$\mathbf{K}$} & \multicolumn{3}{|c|}{ Ca } \\
\hline 0 & $28.0 \mathrm{~d}$ & $29.4 d$ & $28.1 \mathrm{~d}$ & $10.6 \mathrm{de}$ & $11.0 \mathrm{~cd}$ & $12.5 \mathrm{ab}$ & $27.4 \mathrm{c}$ & $32.0 \mathrm{bc}$ & $30.9 b c$ & $8.73 a b$ & $8.92 \mathrm{ab}$ & $98.54 b$ \\
\hline 10 & $33.3 \mathrm{c}$ & $35.2 b c$ & $36.4 b c$ & $9.45 \mathrm{ef}$ & $11.7 b c$ & $13.2 \mathrm{a}$ & $32.0 \mathrm{bc}$ & $30.0 \mathrm{bc}$ & $33.1 \mathrm{~b}$ & $8.84 \mathrm{ab}$ & $9.54 \mathrm{ab}$ & $10.8 \mathrm{ab}$ \\
\hline 20 & $45.3 \mathrm{a}$ & $36.4 b c$ & $27.6 \mathrm{~d}$ & $12.0 \mathrm{abc}$ & $12.0 \mathrm{abc}$ & $12.2 \mathrm{abc}$ & $43.0 \mathrm{a}$ & $33.0 \mathrm{~b}$ & $34.2 b$ & $10.3 \mathrm{ab}$ & $10.6 \mathrm{ab}$ & $9.19 \mathrm{ab}$ \\
\hline \multirow[t]{2}{*}{30} & $37.5 b$ & $29.0 \mathrm{~d}$ & $28.4 \mathrm{~d}$ & $9.92 \mathrm{df}$ & $9.34 \mathrm{f}$ & $10.1 \mathrm{def}$ & $402 \mathrm{a}$ & $32.4 b$ & $40.2 \mathrm{a}$ & $9.02 \mathrm{ab}$ & $10.5 \mathrm{ab}$ & $11.1 \mathrm{a}$ \\
\hline & \multicolumn{3}{|c|}{ Mg } & \multicolumn{3}{|c|}{$\mathbf{C u}$} & \multicolumn{3}{|c|}{ Mg } & \multicolumn{3}{|c|}{$\mathbf{C u}$} \\
\hline 0 & $4.28 \mathrm{e}$ & $4.86 \mathrm{de}$ & $4.96 \mathrm{de}$ & $13.5 \mathrm{a}$ & $11.9 \mathrm{~b}$ & $9.66 \mathrm{cde}$ & $3.87 \mathrm{e}$ & $4.42 \mathrm{de}$ & $4.55 \mathrm{cde}$ & $11.9 \mathrm{a}$ & $11.1 \mathrm{a}$ & $9.22 \mathrm{~b}$ \\
\hline 10 & $5.48 \mathrm{~cd}$ & $5.50 \mathrm{~cd}$ & $7.08 \mathrm{~b}$ & $10.3 \mathrm{c}$ & $9.16 \mathrm{e}$ & $10.0 \mathrm{c}$ & $4.84 \mathrm{cde}$ & $4.88 \mathrm{cde}$ & $5.42 \mathrm{bcd}$ & $10.5 \mathrm{a}$ & $8.69 b$ & $8.64 b$ \\
\hline \multirow[t]{2}{*}{30} & 7.39ab & $5.77 \mathrm{c}$ & $7.45 \mathrm{ab}$ & $8.78 \mathrm{ef}$ & $9.23 \mathrm{de}$ & $8.06 f$ & $6.62 \mathrm{a}$ & $5.57 \mathrm{abc}$ & $6.51 \mathrm{a}$ & $8.46 b$ & $10.4 \mathrm{a}$ & $8.37 \mathrm{~b}$ \\
\hline & \multicolumn{3}{|c|}{ Zn } & & & & \multicolumn{3}{|c|}{ Zn } & & & \\
\hline 0 & $59.3 \mathrm{ab}$ & $63.9 \mathrm{a}$ & $50.8 \mathrm{~cd}$ & & & & $57.3 \mathrm{a}$ & $57.3 \mathrm{a}$ & $50.6 \mathrm{ab}$ & & & \\
\hline 10 & $59.4 \mathrm{ab}$ & $61.4 \mathrm{a}$ & $59.5 \mathrm{ab}$ & & & & $53.2 \mathrm{ab}$ & $49.7 \mathrm{abc}$ & $52.9 \mathrm{ab}$ & & & \\
\hline 20 & $63.4 \mathrm{a}$ & $53.9 \mathrm{bc}$ & $47.1 \mathrm{~d}$ & & & & $49.6 \mathrm{bc}$ & $41.1 \mathrm{de}$ & $47.2 \mathrm{bcde}$ & & & \\
\hline 30 & $53.6 \mathrm{bc}$ & $57.9 \mathrm{ab}$ & $40.9 \mathrm{e}$ & & & & $48.6 \mathrm{bcd}$ & $42.3 \mathrm{cde}$ & $39.6 \mathrm{e}$ & & & \\
\hline
\end{tabular}

$\mathrm{Cu}$ and $\mathrm{Zn}$ in $\mathrm{mg} / \mathrm{kg}$; all other nutrients in $\mathrm{g} / \mathrm{kg}$

Mean of four replicates. Mean value followed by different letters in the shaded block for each variable significantly differ at the $5 \%$ level, according to the adjusted turkey test 
significantly higher residual tissue $\mathrm{N}$ content over $\mathrm{N}$ alone class in soil 1 . The observed change in residual tissue $\mathrm{N}$ concentration under biochar application could indicate mineralization was taking place in the 2 nd growing cycle. In both experiments, biochar with and without $\mathrm{N}$ classes promoted significant tissue $\mathrm{Mg}$ concentration compared with the control and $\mathrm{N}$ alone classes over both growing cycles (Additional file 2: Table 4S, 5S). Similarly, Uzoma et al. (2011) reported that cow manure biochar addition at high application rate $\left(20 \mathrm{tha}^{-1}\right)$ significantly enhanced maize grain $\mathrm{Mg}$ content. The concentrations of tissue $\mathrm{Ca}$ were very high under biochar with $\mathrm{N}$ class in both soils over both growing cycles (Additional file 2: Table 4S, 5S). This result was in agreement with Gaskin et al. (2010) and Kloss et al. (2014), who reported that combined application of biochar with $\mathrm{N}$ significantly increased tissue $\mathrm{Ca}$ concentration of plants.

Copper, an essential micronutrient, plays an important role in a vast number of metalloenzymes and membrane structure (Hansch and Mendel 2009). In the 1st growing cycle of both experiments, the tissue $\mathrm{Cu}$ concentrations of lettuce plants grown under all treatments, except the highest biochar and $\mathrm{N}$ fertilizer combination $\left(30 \mathrm{tha}^{-1}\right.$ with $50 \mathrm{~kg} \mathrm{~N} \mathrm{ha}^{-1}$ ) on soil 2, were slightly above the optimum range (Tables 3, 4) (Hartz and Johnstone 2007). For both soils, tissue $\mathrm{Cu}$ concentration of biochar alone classes were significantly smaller than the controls (Additional file 2: Table 4S, 5S). In agreement with the findings of the present study, Karami et al. (2011) and Park et al. (2011) reported that the application of biochar led to a reduction of plant $\mathrm{Cu}$ concentrations compared to the controls. However, an increase in tomato $\mathrm{Cu}$ concentration under the application of wastewater sludge biochar was reported by Hossain et al. (2010). The addition of P-rich soil amendments reduces the mobility of various trace elements and corresponding accumulation in plant tissue (Cao et al. 2002; Brown et al. 2004, 2005; Kumpiene et al. 2008; Cao et al. 2009). For example, in tall fescue, application of high dosages of $\mathrm{P}$ have resulted in low tissue $\mathrm{Zn}$ concentration as compared to the control treatment (Brown et al. 2004). Similar result has been obtained for rye grass under high $\mathrm{P}$ application (Brown et al. 2005). In our case, despite the high P load of faecal matter biochar there was no discernible trend towards a decrease in tissue $\mathrm{Zn}$ concentration with increased biochar application. This was partly attributed to the accompanied $\mathrm{Zn}$ load (high) of the biochar. However, the highest biochar and $\mathrm{N}$ fertilizer combination $\left(30 \mathrm{tha}^{-1}\right.$ with $50 \mathrm{~kg} \mathrm{~N} \mathrm{ha}^{-1}$ ) induced statistically the lowest tissue $\mathrm{Zn}$ concentrations in soil 2 over both growing cycles. In the same soil, the tissue $\mathrm{Zn}$ concentration showed a decreasing trend with increasing biochar level only at $\mathrm{N}$ fertilizer application rate of $50 \mathrm{~kg} \mathrm{ha}^{-1}$.
Although several studies have been conducted on the agronomic performance of various biochars (Chan et al. 2007; Asai et al. 2009; Uzoma et al. 2011), all these studies assessing the effect of biochar on crop yield and tissue nutrient concentrations were conducted using biochars produced from plant and manure-based feedstocks. In the current study, human excreta, which is commonly disposed of and causes environmental and health hazards in developing countries, was used as a feedstock for biochar production and its valuable nutrients and organic compounds were returned to soils. Therefore, it can be inferred that higher yield and tissue nutrient concentrations of lettuce plants could be highly associated with nutrient supplying potential of the faecal matter biochar, particularly P, K and Mg.

\section{Conclusion}

The study showed that the greatest absolute yield effects of faecal matter biochar addition (with or without $\mathrm{N}$ ) were seen in moderately fertile silty loam soil than less fertile sandy loam soil. However, the greatest biochar addition effects (with or without $\mathrm{N}$ ) with regard to relative yield were seen in less fertile sandy loam soil. For both soils, the biochar application rates of 20 and $30 \mathrm{t} \mathrm{ha}^{-1}$ with $50 \mathrm{~kg} \mathrm{~N} \mathrm{ha}^{-1}$ were found to significantly increase above ground biomass when compared to most treatment combinations and control. Therefore, faecal matter biochar application at a rate of $20 \mathrm{t} \mathrm{ha}^{-1}$ is recommended for considerable shoot yield under the conditions of these experiments. Although both biochar alone and biochar with $\mathrm{N}$ classes induced significant residual yield increase, the yield response of the two classes was non-significant, suggesting the low residual effect of $\mathrm{N}$ in yield response of lettuce. Generally, our results suggest that biochar from faecal matter could be used as an effective fertilizer to achieve high yield of lettuce in less fertile sandy loam and moderately fertile silty loam soils. Moreover, the conversion of the faecal matter feedstock into charred product may offer additional waste management benefit as it offers an additional (microbiologically safe) product compared to the more common co-composting. However, cost assessments are required to calculate the net benefit of the biochar production (on farm) and applications from farmers' perspective.

\section{Additional files}

Additional file 1. Surface and chemical properties of faecal matter biochar.

Additional file 2. Class means and contrasts of class for mineral concentrations (dry weight) of lettuce grown in soil 1 and soil 2 over two growing cycles. 


\section{Authors' contributions}

DW, PD and BM conceived and designed the study. DW conducted the biochar, soil and plant analysis. DW, PD and BM contributed to the analysis and interpretation of data. DW drafted the manuscript. DW, PD, BM, FI, and $\mathrm{HG}$ revised the draft manuscript. All authors read and approved the final manuscript.

\section{Author details}

1 School of Natural Resources Management and Environmental Sciences, Haramaya University, 138, Dire Dawa, Ethiopia. ${ }^{2}$ International Water Management Institute, Colombo, Sri Lanka. ${ }^{3}$ Department of Soil Science/Soil Ecology, Ruhr-Universitat Bochum, Bochum, Germany. ${ }^{4}$ Department of Crop Science, University of Nambia, Windhoek, Namibia.

\section{Acknowledgements}

This work was supported by the WLE program led by the International Water Management Institute (IWMI-CGIAR), the Department of Soil Science/Soil Ecology, Ruhr-Universitat Bochum, the Urban Food Plus project of the German Federal Ministry of Education and Research and the Ministry of Education of Ethiopia. Biochar was produced in Akaki Basic Metals Industry, Addis Ababa, Ethiopia. We also wish to acknowledge National Soil Testing Center for allowing us to use their glasshouse and are grateful to the staff of soil laboratory in Bochum for their assistance. We would also like to thank the two anonymous reviewers for their constructive comments and improvements to the manuscript.

\section{Competing interests}

The authors declare that they have no competing interests.

Received: 17 March 2016 Accepted: 1 January 2017

Published online: 10 January 2017

\section{References}

Abbasi MK, Anwar AA (2015) Ameliorating effects of biochar derived from poultry manure and white clover residues on soil nutrient status and plant growth promotion-greenhouse experiments. PLOS ONE 10(6):e0131592. doi:10.1371/journal.pone.0131592

Agegnehu G, Bass AM, Nelson PN, Muirhead B, Wright G, Bird MI (2015) Biochar and biochar-compost as soil amendments: effects on peanut yield, soil properties and greenhouse gas emissions in tropical North Queensland, Australia. Agric Ecosyst Environ 213:72-85

Alburquerque JA, Salazar P, Barrón V, Torrent J, del Campillo MC, Gallardo A, Villar R (2013) Enhanced wheat yield by biochar addition under different mineral fertilization levels. Agron Sustain Dev 33:475-484

Antal MJ Jr, Grønli M (2003) The art, science, and technology of charcoal production. Ind Eng Chem Res 42:1619-1640

Asai H, Samson KB, Stephan MH, Songyikhangsuthor K, Homma K, Kiyono Y, Inoue Y, Shiraiwa T, Horie T (2009) Biochar amendment techniques for upland rice production in Northern Laos 1. Soil physical properties, leaf SPAD and grain yield. Field Crops Res 111:81-84

Biederman LA, Harpole WS (2013) Biochar and its effects on plant productivity and nutrient cycling: a meta-analysis. Glob Chang Biol Bioenergy 5:202-214

Blackwell P, Krull E, Butler G, Herbert A, Solaiman Z (2010) Effect of banded biochar on dryland wheat production and fertiliser use in southwestern Australia: an agronomic and economic perspective. Aust J Soil Res 48:531-545

Boehm HP (1994) Some aspects of the surface chemistry of carbon blacks and other carbons. Carbon 32:759-769

Bridle TR, Pritchard D (2004) Energy and nutrient recovery from sewage sludge via pyrolysis. Water Sci Technol 50:169-175

Brown S, Chaney R, Hallfrisch J, Ryan JA, Berti WR (2004) In situ soil treatments to reduce the phyto- and bioavailability of lead, zinc, and cadmium. J Environ Qual 33:522-531

Brown S, Christensen B, Lombi E, McLaughlin M, McGrath S, Colpaert J, Vangronsveld J (2005) An inter-laboratory study to test the ability of amendments to reduce the availability of $\mathrm{Cd}, \mathrm{Pb}$, and $\mathrm{Zn}$ in situ. Environ Pollut 138:34-45
Brunauer S, Emmett P, Teller E (1938) Adsorption of gases in multimolecular layers. J Am Chem Soc 60:309-319

Calderón FJ, McCarty GW, Reeves JB III (2006) Pyrolisis-MS and FT-IR analysis of fresh and decomposed dairy manure. J Anal Appl Pyrolysis 76:14-23

Cantrell KB, Hunt PG, Uchimiya M, Novak JM, Ro KS (2012) Impact of pyrolysis temperature and manure source on physicochemical characteristics of biochar. Bioresour Technol 107:419-428

Cao XD, Harris WG (2010) Properties of dairy manure-derived biochar pertinent to its potential use in remediation. Bioresour Technol 101:5222-5228

Cao XD, Ma LQ, Chen M, Singh SP, Harris WG (2002) Impacts of phosphate amendments on lead biogeochemistry at a contaminated site. Environ Sci Technol 36:5296-5304

Cao XD, Ma LN, Gao B, Harris W (2009) Dairy-manure derived biochar effectively sorbs lead and atrazine. Environ Sci Technol 43:3285-3291

Chan KY, Van Zwieten L, Meszaros IA, Downie A, Joseph S (2007) Agronomic values of greenwaste biochar as a soil amendment. Aust J Soil Res 45:629-634

Chan KY, Van Zwieten L, Meszaros I, Downie A, Joseph S (2008) Using poultry litter biochars as soil amendments. Aust J Soil Res 46:437-444

Cheng CH, Lehmann J, Thies JE, Burton SD, Engelhard MH (2006) Oxidation of black carbon through biotic and abiotic processes. Org Geochem 37:1477-1488

Cleaver TS, Greenwood DJ (1975) Ready reckoner to predict best fertilizer for vegetables. Grower 83:1269-1271

DIN ISO 10730 (2009) Soil quality-extraction of trace elements from soil using ammonium nitrate. Deutsches Institut für Normung e.V., Berlin

Enders A, Hanley K, Whitman T, Joseph S, Lehmann J (2012) Characterization of biochars to evaluate recalcitrance and agronomic performance. Bioresour Technol 114:644-653

Fytili D, Zabaniotou A (2008) Utilization of sewage sludge in EU application of old and new methods-a review. Renew Sust Energ Rev 12:116-140

Gaskin JW, Speir A, Morris LM, Ogden L, Harris K, Lee D, Das KC (2007) Potential for pyrolysis char to affect soil moisture and nutrient status of loamy sand soil. In: Proceedings of the 2007 Georgia water resources conference, University of Georgia, Atlanta, 27-29 March 2007

Gaskin JW, Steiner C, Harris K, Das KS, Bibens B (2008) Effect of low temperature pyrolysis conditions on biochar for agricultural use. Trans ASABE 51:2061-2069

Gaskin JW, Speir RA, Harris K, Das KC, Lee RD, Morris LA, Fisher DS (2010) Effect of peanut hull and pine chip biochar on soil nutrients, corn nutrient status, and yield. Agron J 102:623-633

Glaser B, Haumaier L, Guggenberger G, Zech W (2001) The 'Terra Preta' phenomenon: a model for sustainable agriculture in the humid tropics. Naturwissenschaften 88:37-41

Glaser B, Lehmann J, Zech W (2002) Ameliorating physical and chemical properties of highly weathered soils in the tropics with charcoal-a review. Biol Fert Soils 35:219-230

Guzha E, Nhapi I, Rockstrom J (2005) An assessment of the effect of human faeces and urine on maize production and water productivity. Phys Chem Earth 30:840-845

Hansch R, Mendel RR (2009) Physiological functions of mineral micronutrients (Cu, Zn, Mn, Fe, Ni, Mo, B, Cl). Curr Opin Plant Biol 12(3):259-266

Hartz TK, Johnstone PR (2007) Establishing lettuce leaf nutrient optimum ranges through DRIS Analysis. HortScience 42:143-146

Hass A, Gonzalez JM, Lima IM, Godwin HW, Halvorson JJ, Boyer DG (2012) Chicken manure biochar as liming and nutrient source for acid Appalachian soil. J Environ Qual 41:1096-1106

Hossain MK, Strezov V, Chan KY, Nelson PF (2010) Agronomic properties of wastewater sludge biochar and bioavailability of metals in production of cherry tomato (Lycopersicon esculentum). Chemosphere 78:1167-1171

Huett DO (1989) Effect of nitrogen on the yield and quality of vegetables. Acta Hortic 247:205-209

Inal A, Gunes A, Sahin O, Taskin M, Kaya E (2015) Impacts of biochar and processed poultry manure applied to a calcareous soil, on the growth of bean and maize. Soil Use Manag 31:106-113

International Biochar Initiative (2014) Standardized product definition and product testing guidelines for biochar that is used in soil. http://www biochar-international.org/sites/default/files/Guidelines_for_Biochar_ That_Is_Used_in_Soil_Final.pdf. Accessed 10 May 2015

Jamali MK, Kazi TG, Arain MB, Afridi HI, Jalbani N, Kandharo GA, Shah AQ, Baig JA (2009) Speciation of heavy metals in untreated sewage sludge 
by using microwave assisted sequential extraction procedure. J Hazard Mater 163:1157-1164

Jiang W, Saxena A, Song B, Ward BB, Beveridge TJ, Myneni SCB (2004) Elucidation of functional groups on gram-positive and gram-negative bacterial surfaces using infrared spectroscopy. Langmuir 20:11433-11442

Johnstone PR, Hartz TK, Cahn MD, Johnstone MR (2005) Lettuce response to phosphorus fertilization in high phosphorus soils. HortScience 40:1499-1503

Karami N, Clemente R, Moreno-Jiménez E, Lepp N, Beesley L (2011) Efficiency of green waste compost and biochar soil amendments for reducing lead and copper mobility and uptake to ryegrass (Lolium perenne). J Hazard Mater 191:41-48

Kimetu JM, Lehmann J, Ngoze SO, Mugendi DN, Kinyangi JM, Riha S, Verchot L, Recha JW, Pell AN (2008) Reversibility of soil productivity decline with organic matter of differing quality along a degradation gradient. Ecosystems 11:726-739

Kiziloglu FM, Turan M, Sahin U, Kuslu Y, Dursun A (2008) Effects of untreated and treated wastewater irrigation on some chemical properties of cauliflower (Brassica olerecea L. var. botrytis) and red cabbage (Brassica olerecea L. var. rubra) grown on calcareous soil in Turkey. Agric Water Manag 95:716-724

Kloss S, Zehetner F, Wimmer B, Buecker J, Rempt F, Soja G (2014) Biochar application to temperate soils: effects on soil fertility and crop growth under greenhouse conditions. J Plant Nutr Soil Sci 177:3-15

Kumpiene J, Lagerkvist A, Maurice C (2008) Stabilization of As, Cr, Cu, Pb and $\mathrm{Zn}$ in soil using amendments-a review. Waste Manag 28:215-225

Lal R (2004) Soil carbon sequestration impacts on global climate change and food security. Science 304:1623-1627

Lal R (2006) Enhancing crop yields in the developing countries through restoration of the soil organic carbon pool in agricultural lands. Land Degrad Dev 17:197-209

Lehmann J, Joseph S (2009) Biochar for environmental management: science and technology. Earthscan, London

Lehmann J, Kern DC, German LA, McCann J, Martins GC, Moreira A (2003) Soil fertility and production potential. In: Lehmann J, Kern DC, Glaser B, Woods WI (eds) Amazonian dark earths: origin, properties, management. Kluwer, Dordrecht, pp 105-124

Liang B, Lehmann J, Solomon D, Kinyangi J, Grossman J, O'Neill B, Skjemstad JO, Thies J, Luizão FJ, Petersen J (2006) Black carbon increases cation exchange capacity in soils. Soil Sci Soc Am J 70:1719-1730

Liu J, Schulz H, Brandl S, Miehtke H, Huwe B, Glaser B (2012) Short term effect of biochar and compost on soil fertility and water status of a Dystric Cambisol in NE Germany under field conditions. J Plant Nutr Soil Sci 175(5):698-707

Lu H, Zhang W, Wang Zhuang S, Zhuang L, Yang Y, Qiu R (2013) Characterization of sewage sludge-derived biochars from different feedstocks and pyrolysis temperatures. J Anal Appl Pyrol 102:137-143

Ludwick AE (ed) (2002) Western fertilizer handbook, 9th edn. Interstate Publishers Inc, Danville, p 356

Muchuweti M, Birkett JW, Chinyanga E, Zvauya R, Scrimshaw MD, Lester JN (2006) Heavy metal content of vegetables irrigated with mixture of wastewater and sewage sludge in Zimbabwe: implications for human health. Agr Ecosyst Environ 112:41-48

Novak JM, Busscher WJ, Laird DL, Ahmedna M, Watts DW, Niandou MAS (2009) Impact of biochar amendment on fertility of a southeastern coastal plain soil. Soil Sci 174:105-112

Pan G, Smith P, Pan W (2009) The role of soil organic matter in maintaining the productivity and yield stability of cereals in China. Agr Ecosyst Environ 129:344-348

Park JH, Choppala GK, Bolan NS, Chung JW, Chuasavathi T (2011) Biochar reduces the bioavailability and phytotoxicity of heavy metals. Plant Soil 348:439-451

Peverill KI, Sparrow LA, Reuter DJ (1999) Soil analysis: an interpretation manual. CSIRO Publishing, Collingwood

Powell JM, Ikpe FN, Somda ZC (1999) Crop yield and fate of nitrogen and phosphorus after application of plant material or feces to soil. Nutr Cycl Agroecosyst 54:215-226

Qiu M, Sun K, Jin J, Gao B, Yan Y, Han L, Wu F, Xing B (2014) Properties of the plant-and manure-derived biochars and their sorption of dibutyl phthalate and phenanthrene. Sci Rep 4:5295
Rajkovich S, Enders A, Hanley K, Hyland C, Zimmerman AR, Lehmann J (2012) Corn growth and nitrogen nutrition after additions of biochars with varying properties to a temperate soil. Biol Fertil Soils 48:271-284

Reibe K, Gotz KP, Rob CL, Doring TF, Ellmer F, Ruess L (2015) Impact of quality and quantity of biochar and hydrochar on soil Collembola and growth of spring wheat. Soil Biol Biochem 83:84-87

Sanchez CA (2000) Response of lettuce to water and nitrogen on sand and the potential for leaching of nitrate-N. HortScience 35:73-77

Singh RP, Agrawal M (2007) Effects of sewage sludge amendment on heavy metal accumulation and consequent responses of Beta vulgaris plants. Chemosphere 67:2229-2240

Singh B, Singh BP, Cowie AL (2010) Characterization and evaluation of biochars for their application as a soil amendment. Aust J Soil Res 4:516-525

Sohi S, Krull E, Lopez-Capel E, Bol R (2010) A review of biochar and its use and function in soil. Adv Agron 105:47-82

Sombroek W, Ruivo ML, Fearnside PM, Glaser B, Lehmann J (2003) Amazonian dark earths as carbon stores and sinks. In: Lehmann J, Kern DC, Glaser B, Woods WI (eds) Amazonian dark earths: origin, properties, management. Kluwer, Dordrecht, pp 125-139

Spokas KA, Cantrell KB, Novak JM, Archer DW, Ippolito JA, Collins HP, Boateng AA, Lima IM, Lamb MC, McAloon AJ, Lentz RD, Nichols KA (2012) Biochar: a synthesis of its agronomic impact beyond carbon sequestration. Environ Qual 41:973-989

Steiner C, Teixeira WG, Lehmann J, Nehls T, MacêDo JLV, Blum WEH, Zech W (2007) Long term effects of manure, charcoal and mineral fertilization on crop production and fertility on a highly weathered Central Amazonian upland soil. Plant Soil 291:275-290

Subedi R, Taupe N, Ikoyi I, Bertora C, Zavattaro L, Schmalenberger A, Leahy JJ, Grignani C (2016) Chemically and biologically-mediated fertilizing value of manure-derived biochar. Sci Total Environ 550(924):933

Tadesse T (1991) Soil, plant, water, fertilizer, animal manure and compost analysis. In: Working Document No. 13. International Livestock Research Center for Africa, Addis Ababa

Tagoe SO, Horiuchi T, Matsui T (2008) Effects of carbonized and dried chicken manures on the growth, yield, and $\mathrm{N}$ content of soybean. Plant Soil 306:211-220

Thompson TL, Doerge TA (1996) Nitrogen and water interactions in subsurface trickle-irrigated leaf lettuce. II. Agronomic, economic, and environmental outcomes. Soil Sci Soc Am J 64:412-418

Unger R, Killorn R (2012) Effect of the application of biochar on selected soil chemical properties, corn grain, and biomass yields in lowa. Commun Soil Sci Plant Anal 42:2441-2451

Uzoma KC, Inoue M, Andry H, Fujimaki H, Zahoor A, Nishihara E (2011) Effect of cow manure biochar on maize productivity under sandy soil condition. Soil Use Manag 27:205-212

Vaccari FP, Baronti S, Lugato E, Genesio L, Castaldi S, Fornasier F, Miglietta F (2011) Biochar as a strategy to sequester carbon and increase yield in durum wheat. Eur J Agron 34:231-238

Van Zwieten L, Kimber S, Morris S, Chan YK, Downie A, Rust J, Joseph S, Cowie A (2010) Effects of biochar from slow pyrolysis of papermill waste on agronomic performance and soil fertility. Plant Soil 327:235-246

Walter I, Martínez F, Cala V (2006) Heavy metal speciation and phytotoxic effects of three representative sewage sludges for agricultural uses. Environ Pollut 139:507-514

Woldetsadik D, Drechsel P, Keraitia B, Marschner B, Itanna F, Gebrekidan H (2016) Effects of biochar and alkaline amendments on cadmium immobilization, selected nutrient and cadmium concentrations of lettuce (Lactuca sativa) in two contrasting soils. SpringerPlus 5:397

Zhang A, Bian R, Pan G, Cui L, Huissain Q, Li L, Zheng J, Zheng J, Zhang X, Han $X$, Yu X (2012a) Effects of biochar amendment on soil quality, crop yield and greenhouse gas emission in a Chinese rice paddy: a field study of 2 consecutive rice growing cycles. Field Crops Res 127:153-160

Zhang A, Liu Y, Pan G, Hussain Q, Li L, Zheng J, Zhang X (2012b) Effect of biochar amendment on maize yield and greenhouse gas emissions from a soil organic carbon poor calcareous loamy soil from Central China Plain. Plant Soil 351:263-275

Zhang P, Sun H, Yu L, Sun T (2013) Adsorption and catalytic hydrolysis of carbaryl and atrazine on pig manure-derived biochars: impact of structural properties of biochars. J Hazard Mater 244:217-224 